\title{
Evidence that the Biofungicide Serenade (Bacillus subtilis) Suppresses Clubroot on Canola via Antibiosis and Induced Host Resistance
}

\author{
R. Lahlali, G. Peng, B. D. Gossen, L. McGregor, F. Q. Yu, R. K. Hynes, \\ S. F. Hwang, M. R. McDonald, and S. M. Boyetchko
}

First, second, third, fourth, fifth, sixth, and ninth authors: Saskatoon Research Centre, Agriculture and Agri-Food Canada, 107 Science Place, Saskatoon, Saskatchewan S7N 0X2, Canada; seventh author: Alberta Agriculture and Rural Development, Crop Development Center North, 17507 Fort Road, Edmonton, Alberta T5Y 6H3, Canada; and eighth author: Department of Plant Agriculture, University of Guelph, Guelph, Ontario N1G 2W1, Canada.

Accepted for publication 24 October 2012.

\begin{abstract}
Lahlali, R., Peng, G., Gossen, B. D., McGregor, L., Yu, F. Q., Hynes, R. K., Hwang, S. F., McDonald, M. R., and Boyetchko, S. M. 2013. Evidence that the biofungicide Serenade (Bacillus subtilis) suppresses clubroot on canola via antibiosis and induced host resistance. Phytopathology 103:245-254.

This study investigated how the timing of application of the biofungicide Serenade (Bacillus subtilis QST713) or it components (product filtrate and bacterial cell suspension) influenced infection of canola by Plasmodiophora brassicae under controlled conditions. The biofungicide and its components were applied as a soil drench at 5\% concentration (vol/vol or equivalent CFU) to a planting mix infested with $P$. brassicae at seeding or at transplanting 7 or 14 days after seeding (DAS) to target primary and secondary zoospores of $P$. brassicae. Quantitative polymerase chain reaction (qPCR) was used to assess root colonization by $B$.

reducing clubroot severity by 62 to $83 \%$. The biofungicide also reduced genomic DNA of P. brassicae in canola roots by 26 to $99 \%$ at 7 and $14 \mathrm{DAS}$, and the qPCR results were strongly correlated with root hair infection $(\%)$ assessed at the same time ( $r=0.84$ to 0.95$)$. qPCR was also used to quantify the transcript activity of nine host-defense-related genes in inoculated plants treated with Serenade at 14 DAS for potential induced resistance. Genes encoding the jasmonic acid (BnOPR2), ethylene (BnACO), and phenylpropanoid (BnOPCL and BnCCR) pathways were upregulated by 2.2 - to 23 -fold in plants treated with the biofungicide relative to control plants. This induced defense response was translocated to the foliage (determined based on the inhibition of infection by Leptosphaeria maculans). It is possible that antibiosis and induced resistance are involved in clubroot suppression by Serenade. Activity against the infection from both primary and secondary zoospores of $P$. brassicae may be required for maximum efficacy against clubroot.
\end{abstract} subtilis as well as $P$. brassicae. The biofungicide was consistently more effective than the individual components in reducing infection by $P$. brassicae. Two applications were more effective than one, with the biofungicide suppressing infection completely and the individual components
Additional keywords: Brassica napus, biofilm, induced systemic resistance, systemic acquired resistance.
Clubroot, caused by the plasmodiophorid pathogen Plasmodiophora brassicae Woronin, is one of the most important diseases of cruciferous crops worldwide (12) and is currently a threat to canola (Brassica napus L.) production in western Canada $(20,22$, 54 ), where $\approx 7$ million ha of canola crops are grown annually. By 2011 , clubroot had been confirmed in $>800$ fields in the province Alberta alone (49). An integrated approach involving use of multiple management tools is generally required for effective management of clubroot disease $(10,13)$. The life cycle of $P$. brassicae consists of a primary infection phase in root hairs and a secondary phase in the root cortex (5). The primary phase starts with infection of root hairs by primary zoospores, followed by the formation of primary plasmodia in root hairs and release of secondary zoospores. The secondary phase starts when secondary zoospores infect the root cortex and form secondary plasmodia. The characteristic clubbing symptom is a consequence of hyperplasia and hypertrophy of the infected tissues (6). Under optimal temperature conditions, the production of primary and secondary zoospore generally peak $\approx 7$ and 14 days after inoculation (48), and these zoospores are considered weak links in the pathogen life cycle (11).

Corresponding author: G. Peng; E-mail address: gary.peng @ agr.gc.ca

http://dx.doi.org/10.1094/PHYTO-06-12-0123-R

(c) 2013 Department of Agriculture and Agri-Food, Government of Canada
Several microorganisms have been reported as potential biocontrol agents (BCAs) against clubroot $(2,7,23,36)$. Peng et al. (41) observed that the biofungicide Serenade (Bacillus subtilis QST713) suppressed clubroot on canola under controlled conditions but its performance was inconsistent under field conditions. The mechanism by which Serenade interferes with $P$. brassicae and clubroot disease is not clear. This B. subtilis strain produces lipopeptide and surfactant antibiotics (25) that showed little suppression of $P$. brassicae resting spores (29). Possibly, it suppresses clubroot via the impact on root-hair and cortical infection by $P$. brassicae zoospores. The genus Bacillus includes a large number of gram-positive bacteria that produce long-lived endospores (14), and these spores may be formulated to target infection from both primary and secondary zoospores of $P$. brassicae in the soil. Some of these Bacillus spp. colonize the plant rhizosphere or are even endophytes $(4,52)$, and protect plants via antibiosis and induced resistance $(1,17)$.

Plants have various mechanisms to defend against invading pathogens (16). Induced systemic resistance (ISR) mediated by Bacillus spp. and Pseudomonas spp. has been reported in several plant species (27). ISR can be associated with the activation of several pathways relating to host-defense response, especially over-synthesis of pathogenesis-related $(\mathrm{PR})$ proteins $(57,58)$ and phenolics (8). Phenylalanine ammonia lyase (PAL) is a key enzyme for phenylpropanoid metabolism that regulates the synthesis of several plant-defense-related metabolites, including phenols, 
phenylpropanoids, and monomers of lignin and salicylic acid (SA). Accumulation of these metabolites is linked to induced plant resistance (18). Rhizobacteria that colonize bean roots trigger the accumulation of the mRNAs that encode PAL and chalcone synthase (61). Also, Bacillus spp. induce resistance against Ralstonia solanacearum and bacterial wilt on tomato (31), and Pseudomonas fluorescens mediates resistance to $P$. syringae pv. tomato in Arabidopsis via activation of the jasmonic acid (JA) and ethylene (Et) pathways (59).

For optimal efficacy of Serenade against clubroot on canola, it is important to understand whether this B. subtilis strain is capable of colonizing canola roots, whether antibiosis and induced resistance are involved in disease suppression, and whether it is necessary to time the treatment against infection by both primary and secondary zoospores. The effect of application timing in relation to the peaks of Plasmodiophora brassicae zoospore release will provide information helpful for designing optimal formulation and delivery to improve the field performance of biofungicides. Therefore, the objectives of the study were to (i) assess efficacy of Serenade and its components in suppressing infection and clubroot severity, (ii) assess the ability of $B$. subtilis strain QST713 to colonize canola roots, and (iii) evaluate the potential for Serenade to mediate ISR in canola based on transcript levels of selected genes encoding plant defense-related metabolic pathways.

\section{MATERIALS AND METHODS}

Biofungicide components, pathogen inoculum, and DNA extraction. Formulated Serenade ASO was diluted with sterile deionized water (SDW) to $5 \%$ ( $\mathrm{vol} / \mathrm{vol}$ ) suspensions that contained bacterial cells at $\approx 5 \times 10^{7} \mathrm{CFU} / \mathrm{ml}$. Product filtrates were produced by filtering the diluted product through a $0.22-\mu \mathrm{m}$ membrane filter (Millipore Corp, Billerica, MA). The filtrate was streaked on nutrient agar to ensure that it was free of bacterial cells. The diluted product and product filtrate preparations were stored at $4^{\circ} \mathrm{C}$ until use. Pure cultures of B. subtilis strain QST713 were isolated from the Serenade product and subcultured on a semiselective Bacillus medium (43) at $25^{\circ} \mathrm{C}$ for $48 \mathrm{~h}$. The lawn of bacterial culture was scraped carefully off the medium with a rubber spatula and suspended in SDW, and the concentration was adjusted to $\approx 5 \times 10^{7} \mathrm{CFU} / \mathrm{ml}$ based on plating counts.

Inoculum for the trial was produced by inoculating a susceptible canola cultivar ('Fortune RR') with $P$. brassicae resting spores from clubbed canola roots collected in a heavily infested field near Leduc, Alberta. The pathogen population in this field consisted predominantly of the pathotype 3 (Williams' system) of $P$. brassicae, which is virulent on canola (50). These mature galls were dried at room temperature for 2 weeks and stored at $-20^{\circ} \mathrm{C}$ until use. When preparing the inoculum, the galls were cut into $\approx 0.5-\mathrm{cm}$ pieces and immersed in $50 \mathrm{ml}$ of SDW for $2 \mathrm{~h}$ to soften the tissue, and $3 \mathrm{~g}$ of dried material was homogenized in a Warring blender at high speed for $1 \mathrm{~min}$. The resulting suspension was filtered through eight layers of cheesecloth, and then the concentration of resting spores was estimated with a hemocytometer and diluted with SDW to $1 \times 10^{7}$ spores $/ \mathrm{ml}$ for soil inoculation.

To develop a molecular method for quantification of $P$. brassicae in roots, the crude resting-spore suspensions described above were purified through repeated centrifugation at $3,500 \times g$ for $10 \mathrm{~min}$ (51). The suspension was centrifuged; then, the pellet resuspended in $5 \mathrm{ml}$ of $50 \%$ sucrose and centrifuged again. The supernatant was then transferred into $30 \mathrm{ml}$ of SDW and centrifuged, and the supernatant was then discarded. The pellet was resuspended in $5 \mathrm{ml}$ of SDW and centrifuged to remove the remaining sucrose. The purified spores were rinsed three times with SDW amended with streptomycin $(100 \mu \mathrm{g} / \mathrm{ml})$ plus centrifugation, and then with SDW prior to storage at $-20^{\circ} \mathrm{C}$ until use.

Genomic DNA (gDNA) of $P$. brassicae from purified resting spores or inoculated canola roots was extracted following the methods described by Sundelin et al. (51). An extract from purified resting spores $\left(1 \times 10^{7}\right.$ spores $\left./ \mathrm{ml}\right)$ was used as a standard for quantitative polymerase chain reaction (qPCR). To extract in planta $P$. brassicae DNA, inoculated roots or controls were shaken lightly to remove soil clumps and washed by constant stirring in 1 liter of tap water in a container for $10 \mathrm{~min}$. The water was changed twice during the washing, and the roots were then rinsed with running tap water for 5 min to remove most microbial propagules on the root surface. Washed roots $(0.2 \mathrm{~g})$ were combined for each treatment, cut into $1-\mathrm{cm}$ pieces, and frozen in liquid nitrogen. gDNA of $P$. brassicae was extracted using a DNeasy Plant Mini Kit (Qiagen, Montreal, QC, Canada) following the manufacturer's instructions. The DNA concentration in each sample was measured using the NanoDrop ND-1000 (NanoDrop Technologies, Wilmington, DE) to ensure that quality standards were met.

Effect of application timing on the components of Serenade. The treatment layout and their intended targets are detailed in Table 1. The treatments or water (control) were applied as a soil drench to pathogen-infested planting mix at seeding time. Seedlings were removed at 7 and 14 days after seeding (DAS) and transplanted into noninfested planting mix treated with Serenade, its components, or water only (control) to estimate the effect on infection caused by primary and secondary zoospores. This design was based on the peak of root-hair infection (RHI) and release of secondary zoospores under optimal temperature conditions (48), and on the protocols previously described by Naiki and Dixon (35) and Tanaka et al. (53) for testing fungicide timing.

Plastic pots $(15 \mathrm{~cm}$ in diameter by $15 \mathrm{~cm}$ tall) were filled with Sunshine number 3 soilless planting mix (SunGro Horticulture,

TABLE 1. Efficacy of Serenade and its components applied at seeding or transplanting of canola against clubroot ${ }^{\mathrm{x}}$

\begin{tabular}{|c|c|c|c|c|}
\hline \multirow[b]{2}{*}{ Zoospores targeted } & \multicolumn{2}{|c|}{ Inoculation/treatment timing } & \multicolumn{2}{|c|}{ Mean disease severity index $(\%)^{\mathrm{y}}$} \\
\hline & At seeding ${ }^{\mathrm{z}}$ & At transplanting & Transplanted at 7 DAS & Transplanted at 14 DAS \\
\hline Control & Plasmodiophora brassicae + water & Water & $83.7 \mathrm{e}$ & $100.0 \mathrm{e}$ \\
\hline \multirow[t]{3}{*}{ A-primary } & P. brassicae + product filtrate & Water & $66.7 \mathrm{de}$ & 80.9 e \\
\hline & P. brassicae + Bacillus subtilis & Water & 40.5 cde & $47.6 \mathrm{~cd}$ \\
\hline & P. brassicae + Serenade & Water & $19.1 \mathrm{bc}$ & $0.0 \mathrm{a}$ \\
\hline \multirow[t]{3}{*}{ B-secondary } & P. brassicae + water & Product filtrate & $57.1 \mathrm{de}$ & $54.8 \mathrm{~cd}$ \\
\hline & P. brassicae + water & B. subtilis & $85.7 \mathrm{e}$ & $52.4 \mathrm{~cd}$ \\
\hline & P. brassicae+ water & Serenade & $23.8 \mathrm{bcd}$ & $16.6 \mathrm{~b}$ \\
\hline \multirow[t]{3}{*}{ C-primary \& secondary } & P. brassicae + Product filtrate & Product filtrate & $21.4 \mathrm{bcd}$ & $23.8 \mathrm{bc}$ \\
\hline & P. brassicae + B. subtilis & B. subtilis & $14.3 \mathrm{~b}$ & $61.9 \mathrm{~cd}$ \\
\hline & P. brassicae + Serenade & Serenade & $0.0 \mathrm{a}$ & $0.0 \mathrm{a}$ \\
\hline
\end{tabular}

\footnotetext{
${ }^{x}$ Means in a column with the same letters do not differ (least significant difference, $P=0.05$ ).

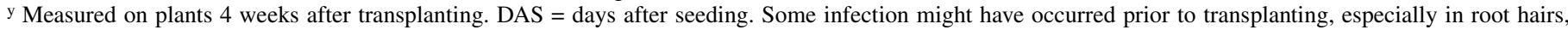
but clubbing symptoms were not visible during transplanting.

z $P$. brassicae was added with or without a Serenade component.
} 
Vancouver, BC, Canada) with a $\mathrm{pH}$ range of 5.8 to 6.3 and soaked twice with water adjusted to $\mathrm{pH} 6.3$ using $2 \mathrm{M}$ HCL. Each pot was then inoculated with $60 \mathrm{ml}$ of a suspension of $P$. brassicae resting spores $\left(1 \times 10^{7}\right.$ spores $\left./ \mathrm{ml}\right)$ to obtain a concentration of $\approx 2 \times 10^{6}$ spores $/ g$. Two days after soil infestation, 50 seeds/pot of Fortune RR canola was planted into the mix at a 1-cm depth. Serenade, product filtrate, and B. subtilis cell suspension at the equivalent of $5 \%$ product concentration were applied as a soil drench at $180 \mathrm{ml} /$ pot. Water $(\mathrm{pH} 7.5)$ was applied to additional plants as a nontreated control. This high product rate and water volume were designed to saturate the growth medium and minimize product dose variation among the plants in a pot. This application method was selected for studying the mode of action only. A previous study showed that a soil-drench treatment with Serenade (at $0.016 \mathrm{ml}$ per conetainer) (described in the following paragraph) in water volumes of $0.6-, 3-$, and $15-\mathrm{ml} /$ conetainer reduced clubroot severity index from $100 \%$ (water control) to 14 , 2 , and $7 \%$, respectively, under controlled conditions (41). There was no substantial difference in clubroot control among these drench volumes applied, which would be equivalent to fieldapplication volumes of 500, 2,500, and 12,500 liters/ha, respectively, based on $10-\mathrm{cm}$ banding in seed furrows with $21-\mathrm{cm}$ row spacing. Seedlings grown in the infested planting mix for 7 and 14 days were removed, and roots of each plant were washed separately in $800 \mathrm{ml}$ of tap water in a 1-liter beaker for $10 \mathrm{~min}$ with constant stirring. The water was changed twice during washing, and the roots were then rinsed in running tap water for another $5 \mathrm{~min}$ to remove most of the P. brassicae and BCA propagules attached to root surfaces. At this point, some infection might have occurred, especially in root hairs, but clubbing symptoms were not visible. To assess the effectiveness of this washing procedure, rinsed roots from the Serenade treatment were cut into $1-\mathrm{cm}$ pieces and 30 pieces were imprinted individually on nutrient agar in a petri dish. Three replicates of imprinted plates were incubated at $25^{\circ} \mathrm{C}$ for 7 days, and the total number of Bacillus spp. colonies recovered on each dish was counted.

Each washed seedling was transplanted individually into noninfested planting mix in a root trainer (conetainer, $3.5 \mathrm{~cm}$ in diameter by $20 \mathrm{~cm}$ tall; Stuewe and Sons, Corvallis, OR). Immediately after transplanting, some transplants were treated again with a soil drench of Serenade or its component at $15 \mathrm{ml} /$ plant to target secondary zoospores released from infected root hairs. Transplants were arranged in a completely randomized design. At 7 and 14 DAS, root-hair colonization by $P$. brassicae was examined using microscopy, and pathogen development in roots was quantified with qPCR. At the end of the trial, clubroot severity was assessed on each plant.

In this experiment, the treatments applied at seeding were intended to suppress infection by primary zoospores (Table 1, target A), treatments applied at transplanting suppressed secondary zoospores (target B), and treatment at both stages were intended to suppress both primary and secondary zoospores. Plants that received $P$. brassicae only (plus water) were used as controls. The experiment was replicated three times, with seven plants in each replicate (experimental unit). Plants, inoculum, and the biofungicide components were prepared independently for each replication in time.

Assessment of RHI, root colonization, and clubroot severity caused by $\boldsymbol{P}$. brassicae. Washed roots from three additional plants of each treatment and the water control were cut into $1-\mathrm{cm}$ pieces, fixed in $70 \%$ alcohol, stained overnight with aceto-carmine $(1 \%)$ or aceto-orcein $(1 \%)$, and examined with a light microscope at $\times 400$ for the presence of primary plasmodium or zoosporangia in root hairs. Up to 40 root hairs were examined for each plant and the incidence of infection recorded.

To determine the amount of $P$. brassicae in root tissues, pathogen gDNA from roots of three additional plants $(0.2 \mathrm{~g}$ fresh weight) was extracted and quantified using a StepOne Real-Time
PCR Detection System (Applied Biosystems Inc., Montreal). This qPCR reaction was performed in $20-\mu \mathrm{l}$ reaction volumes containing $2 \mu \mathrm{l}$ of template DNA, $0.1 \mu \mathrm{l}$ of each primer $(50 \mathrm{nM})$, $10 \mu \mathrm{l}$ of SYBR Green-I PCR Master Mix (Applied Biosystems), and $7.8 \mu \mathrm{l}$ of sterile deionized water. The thermocycling profile consisted of an initial denaturation step of $10 \mathrm{~min}$ at $95^{\circ} \mathrm{C}$, then 50 cycles of $15 \mathrm{~s}$ at $95^{\circ} \mathrm{C}$, and $1 \mathrm{~min}$ at $60^{\circ} \mathrm{C}$. The cycle threshold $\left(\mathrm{C}_{\mathrm{t}}\right)$ levels were set automatically by the system, and the quantification was carried out using a standard curve developed using serial dilutions $\left(1 \times 10^{0}\right.$ to $\left.1 \times 10^{-4} \mathrm{ng}\right)$ of gDNA extracted from purified $P$. brassicae resting spores. qPCR reactions were conducted using the specific primers Pb4-1 (TACCATACCCAGG GCG-ATT) and PbITS6 (CAACGAGTCAGCTTGAATGC), described previously by Sundelin et al. (51). For each sample, three repeated reactions were conducted to establish standard linear regression curves between $C_{t}$ values and the logarithm of template concentrations. A melting curve analysis was performed at the end of reaction to ensure that only the target DNA was amplified (51).

At 4 weeks after transplanting, each plant was assessed for clubroot severity using a 0 to 3 scale (50), in which $0=$ no galling; $1=$ small galls only on less than one-third of roots; $2=$ small or medium-sized galls on one-third to two-thirds of roots; and $3=$ severe galling, medium- to large-sized galls with more than twothirds of roots affected. A disease severity index (DSI) was calculated over all of the plants in an experimental unit using the following formula: DSI $(\%)=[(\Sigma$ [rating class $\times$ number of plants in the rating class])/(total number of plants in the treatment run $\times$ highest rating scale) $] \times 100$.

Colonization of canola roots by $B$. subtilis. To assess the relative size of BCA population, roots removed at 14 DAS were washed and bacterial gDNA was extracted and quantified with qPCR under the following conditions: $10 \mathrm{~min}$ at $95^{\circ} \mathrm{C}$, followed by 45 cycles of $15 \mathrm{~s}$ at $95^{\circ} \mathrm{C}$ for denaturation, then $1 \mathrm{~min}$ at $60^{\circ} \mathrm{C}$ for annealing and extension using the $B$. subtilis-specific primer $\mathrm{F}$ (5'-GCG GCG TGC CTA ATA CAT GC-3') and primer R (5'CTC AGG TCG GCT ACG CAT CG-3') (24). The amount of $B$. subtilis DNA was estimated using a calibration curve based on fivefold dilutions of bacterial DNA samples of 100 to $0.16 \mathrm{ng}$. A melting curve analysis was also performed to ensure that only one product was amplified during qPCR. Each of the samples had a single peak, indicating a pure PCR product without contamination or primer dimer formation.

To assess the potential for this $B$. subtilis strain as an endophyte in canola roots, some washed roots were surface disinfested in $70 \%$ alcohol for $5 \mathrm{~s}$ and $0.12 \%$ hypochlorite for $2 \mathrm{~min}$, rinsed in SDW twice, cut into $1-\mathrm{cm}$ pieces, and incubated (30 pieces/plate) on the semiselective Bacillus medium (43) at $25^{\circ} \mathrm{C}$ for 7 days for the incidence of $B$. subtilis colonies. To assess the effectiveness of the washing and surface disinfestation in removing B. subtilis population on the root surface, additional control plants were treated with a soil drench of Serenade at $25 \mathrm{ml} /$ pot at $\approx 14 \mathrm{DAS}$. Then, 30 min later, roots were removed, washed, or surface disinfested using the protocols described earlier and homogenized using a mortar and pestle in $10 \mathrm{ml}$ of water. Serial dilutions were made and suspensions plated on the semiselective medium at $25^{\circ} \mathrm{C}$ for 7 days for bacterial enumeration.

Defense responses in canola induced by $B$. subtilis. Response in cotyledons and first true leaves. Blackleg on canola, caused by Leptosphaeria maculans, originates typically from early infections on cotyledons or young leaves (60); therefore, the reaction on cotyledons has been carefully examined. The reaction to cotyledon inoculation in susceptible canola seedlings was used to assess whether a soil drench application of Serenade induced production and translocation to the cotyledons of products responsible for induced resistance.

At 14 DAS, the cotyledons and first true leaves of canola seedlings ('Westar') treated with a soil drench of Serenade were 
inoculated with a virulent isolate of L. maculans. Approximately $10-\mu l$ conidial suspensions $\left(2 \times 10^{7} / \mathrm{ml}\right)$ of $L$. maculans were applied to a wound made with a pair of forceps at the center of a cotyledon or true leaf. Each experimental unit consisted of 12 plants (replicate), with 24 cotyledons or 12 first true leaves inoculated. Drops of $10 \mu \mathrm{l}$ of SDW applied to wounds were used as negative controls. The experiment was arranged in a completely randomized design with three replicates, and was conducted twice. The growing point and true leaves of plants with inoculated cotyledons were removed after inoculation to extend the life of the cotyledons. The inoculated seedlings were maintained in a growth cabinet for 15 days. Blackleg severity was assessed at 3-day intervals using a 0 to 9 scale (37), which was converted into a DSI using the formula described above for calculating clubroot DSI.

Expression of plant hormone pathways and defense-related genes. At 14 DAS, roots from three treated canola plants were washed as described above and RNA was extracted using an RNeasy Plant Mini Kit (Qiagen). RNA from the first true leaves of each plant was extracted separately, and samples from watertreated plants were used as controls. Total RNA ( $5 \mu \mathrm{g}$, free of DNA) was converted to cDNA using Super Script Strand Synthesis (Invitrogen, Burlington, ON, Canada) following the manufacturer's instructions. To determine the relative expression of plant-defense-related genes, the primers listed in Table 2 were used with qPCR in the following steps: a $2-\mu \mathrm{gDNA}$ sample was brought to a total reaction volume of $\approx 20 \mu \mathrm{l}$ with $10 \mu \mathrm{l}$ of SYBER Green-I, $0.5 \mu \mathrm{l}(50 \mathrm{nM})$ of each primer, and $7 \mu \mathrm{l}$ of DEPC-water ( $1 \mathrm{ml}$ of $0.1 \%$ diethylpyrocarbonate [DEPC] in $1,000 \mathrm{ml}$ of distilled water). PCR amplification was carried out for each target gene using conditions specific to that gene, as reported previously $(46,62)$. The Actin gene was used as the housekeeping gene control for qPCR (62). The relative expression ratio of a target gene was measured using the StepOne v2.1 software (Applied Biosystems) based on the $\mathrm{C}_{\mathrm{t}}$ for both treated and control plants, and differences in relative expression of each gene were determined using least significant difference (LSD) $(P \leq 0.05)$. There were three replicates per sample and the trial was conducted twice.

Statistical analysis. Statistical analyses of data were carried out with the Statistical Analysis System (version 9.1; SAS Institute, Cary, NC). Logarithm or arcsine transformations were used to normalize data distribution for DSI. Data from each of the repeated trials were homogeneous based on Bartlett's Test and, therefore, were pooled prior to analysis. Analysis of variance (ANOVA) was performed using PROC GLM. In each of the trials with two factors, interaction between the factors was not significant; therefore, only the main effects are reported. Treatment means were separated using $\mathrm{LSD}_{0.05}$ when the ANOVA was significant (at $P \leq 0.05$ ). The mean and standard error values presented are based on nontransformed data.

\section{RESULTS}

Effect of application timing on efficacy of Serenade and its components. At both 7 and 14 DAS, Serenade and its components reduced the incidence of RHI substantially relative to the water control (pathogen inoculated) (Fig. 1). The formulated biofungicide, which reduced the incidence of RHI by 96 and $94 \%$ at 7 and 14 DAS, respectively, relative to the control, was more effective than product filtrate or B. subtilis applied alone. There was an overall trend of increase in RHI between 7 and 14 DAS (ANOVA, $P<0.05$ ).

There was a strong linear relationship $(y=-3.22 \log 10[x]+$ $19.08, r=1)$ between the $\mathrm{C}_{\mathrm{t}}$ values on $\mathrm{qPCR}$ and the amount of $P$. brassicae DNA samples (REGRESSION, $P<0.0001$ ). The threshold fluorescence signal for the DNA from purified resting spores of $P$. brassicae was 0.22 and the melting point for the amplification product was 78.87 . The amount of $P$. brassicae DNA in canola roots was affected by the treatment, with the Serenade being most effective, followed by the product filtrate and bacterial cell suspension at both 7 and 14 DAS (Fig. 2). These trends on $P$. brassicae DNA were positively correlated with RHI at 7 DAS $(r=0.95)$ and 14 DAS $(r=0.84)$, and with DSI $(r=$ 0.60 to 0.76 ) at 35 to 42 days after transplanting.

Colonization of canola roots by $B$. subtilis. There was a strong linear relationship between $C_{t}$ values and amounts of $B$. subtilis DNA in root samples $(y=-6.90 \log 10[x]+29.75, r=$ 0.99). Bacterial DNA was detected in roots treated with Serenade or B. subtilis alone (Fig. 3) but not in roots treated with the product filtrate alone or water $(<0.16 \mathrm{ng} / \mathrm{g}$ root $)$. The amount of $B$. subtilis DNA was higher in Serenade-treated roots relative to $B$. subtilis-treated roots (Fig. 3), and increased between 7 and 14 DAS (ANOVA, $P<0.05$ ).

For plants treated with Serenade at seeding and removed at 14 DAS, surface sterilization (disinfestation) and washing both reduced Bacillus spp. significantly on the root surface (LSD, $P<$ $0.05)$, decreasing the bacterial population from 5.2 to 0.7 and 1.1 CFU/root piece, respectively, based on root imprint results. However, neither method eliminated the bacterial population on the root surface entirely. For plants treated with Serenade for only $30 \mathrm{~min}$, although washing and surface disinfestation reduced Bacillus spp. population substantially, a large number of live bacterial cells remained (Fig. 4). Washed roots of control plants showed Bacillus spp. at $0 \mathrm{CFU} / \mathrm{g}$ root (data not shown).

Effect of application timing on clubroot development. Plants inoculated with $P$. brassicae at seeding and transplanted at 7 or 14 DAS (after root washing) into noninfested planting mix developed severe clubroot symptoms 4 weeks after transplanting (Table 1), with higher DSI on plants transplanted at 14 DAS than those transplanted at 7 DAS. Serenade applied at seeding, transplanting, or at both seeding and transplanting reduced club-

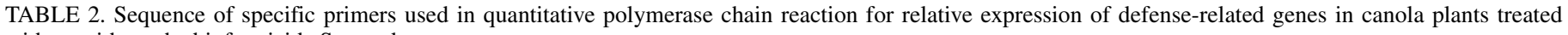
with or without the biofungicide Serenade

\begin{tabular}{|c|c|c|c|c|}
\hline $\begin{array}{l}\text { Gene } \\
\text { family }\end{array}$ & $\begin{array}{l}\text { Metabolic } \\
\text { pathways }^{x}\end{array}$ & Forward primer & Reverse primer & Ref. ${ }^{y}$ \\
\hline $\mathrm{BnCCR}$ & Phenylpropanoid & 5'-AGCCGAAAAGCTGCTTGGAG-3' & 5'-TAGCCAACCGATTCACATCC-3' & 62 \\
\hline $\mathrm{BnOPCL}$ & Phenylpropanoid & 5'-GTACAAGAGGGTACGAAAAGTGG-3' & 5'-TGGGTAAACCATCCTCAGG-3' & 62 \\
\hline BnSAM3 & Ethylene & 5'-AGCTACGGAATGGGAAGATAC-3' & 5'-AAGACCTGAGAGAACTAAAC-3' & 62 \\
\hline $\mathrm{BnACO}$ & Ethylene & 5'-CATTCTACAACCCTGGAAGCGAC-3' & 5'-ATGGTCCAACATTGTTGGCCAC-3' & 62 \\
\hline BnOPRA2 & Jasmonic acid & 5'-TGTCCTCACTTGCTACCGATGAGG-3' & 5'-GGATCAGAAGTGTAAAACGTTGGC-3' & 62 \\
\hline BnAA01 & Auxin & 5'-GAATGGAACATCCACCAGAAGAAG-3' & 5'-TGTGCTCATGTCATGTCTG-3' & 62 \\
\hline BnPR-1 & PR proteins & 5'ATGAAAGTCACTAACTGTTCTCGAC-3' & 5'-GCCAGTAAACTAGGTAACGGATAA-3' & 46 \\
\hline BnPR-2 & PR proteins & 5'-GTGTTAGCATCATCACCAATGTTGCTG-3' & 5'-GGAGATTAGTTAAACTTAACACCATATTTAAGCTG-3' & 46 \\
\hline BnPR-5 & PR proteins & 5'-CAATGGCTTCACGAAACCTCTTCAACTTCG-3' & 5'-GTGATTTTAACGGCGATGGTGAGGGCAAAA-3' & 46 \\
\hline BnActin $^{\mathrm{z}}$ & Actin & 5'-AAGAGCAGTTCTTGGGTGGA-3' & 5'-TACTTCAGGGCAACGGAATC-3' & 62 \\
\hline
\end{tabular}

${ }^{x} \mathrm{PR}=$ pathogenesis-related.

y Reference number.

z Used as a house-keeping gene. 
root most effectively, and the two-application treatment controlled clubroot completely. Applying Serenade at seeding and then transplanting the plants into noninfested growth medium at 14 DAS also prevented clubroot completely. The product filtrate or B. subtilis alone were less effective than Serenade, especially when applied only once at seeding or transplanting (Table 1).

Defense responses in canola induced by $\boldsymbol{B}$. subtilis. Response in cotyledons and first true leaves. Lesions on cotyledons resulting from L. maculans inoculation expanded with time on both Serenade-treated and control plants but the rate of expansion was slower on treated plants (Fig. 5) initially. DSI was substantially lower on treated plants than on control for up to 12 days after inoculation, although the difference disappeared by day 15 . The lesions on the first true leaves developed little for both treated and control plants during the 15 days of observation.

Expression of plant hormone pathways and defense-related genes. For nine of the plant-defense-related genes evaluated, the genes BnCCR and BnOPCL encoding the phenylpropanoid pathway were upregulated by 23 - and-4 fold in leaves and 2.5 - and 2.2 -fold in roots of Serenade-treated plants $(P<0.0001)$, respectively, relative to water controls (Fig. 6). Transcript levels for BnOPR2 and BnACO, which are involved in the JA and Et biosynthesis pathways, respectively, increased by approximately twofold in roots $(P<0.001)$ but little in leaves. None of the PR protein genes was upregulated by the Serenade treatment.

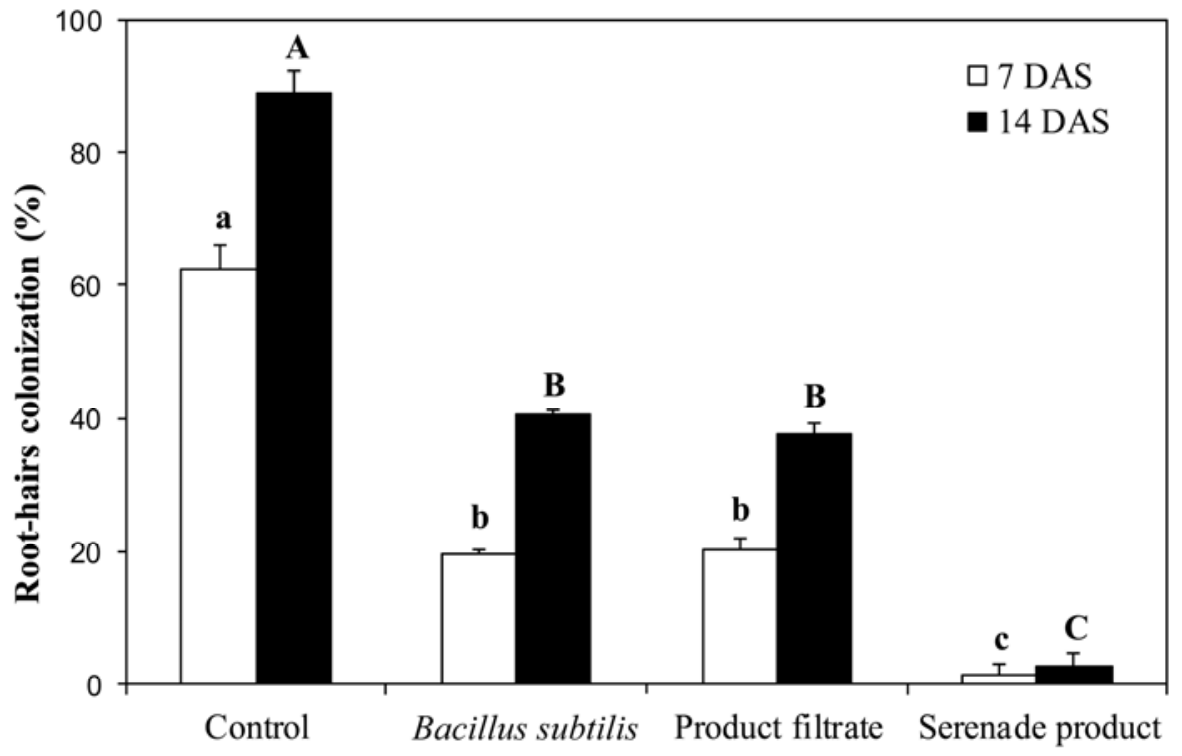

Treatment

Fig. 1. Influence of selected Serenade components on infection of canola root hairs by Plasmodiophora brassicae at 7 and 14 days after seeding (DAS). Bars represent the average of six replicates for each treatment. Mean values of root-hair infection at 7 DAS (lowercase letters) or 14 DAS (uppercase letters) marked with different letters are significantly different (least significant difference, $P<0.05$ ). Capped lines represent standard errors.

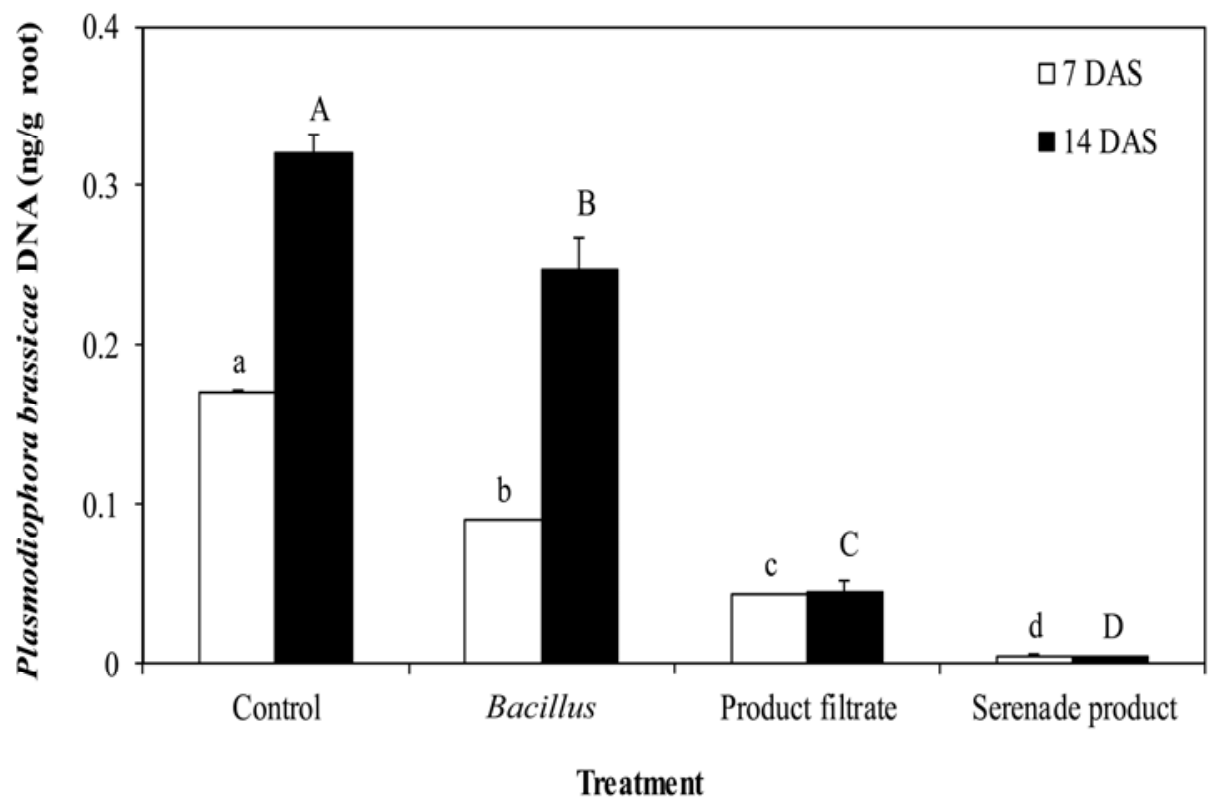

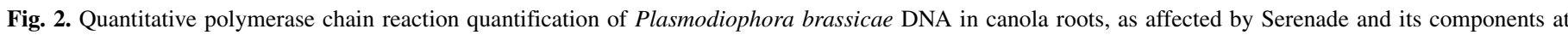

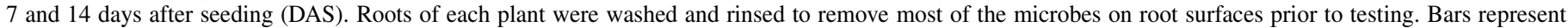

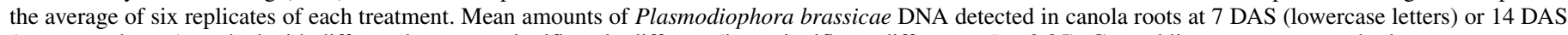
(uppercase letters) marked with different letters are significantly different (least significant difference, $P<0.05$ ). Capped lines represent standard errors. 


\section{DISCUSSION}

The current study indicates that the biofungicide Serenade suppresses clubroot on canola, likely via at least antibiosis (Figs. 1 and 2; Table 1) and induced resistance (Figs. 5 and 6). The observation that two applications (at seeding and at transplanting) were generally more effective than one treatment after seeding or transplanting highlights the importance of keeping a high dose of biofungicide in the soil, because this may reduce infection by primary and secondary zoospores of $P$. brassicae. This requirement, however, poses a challenge to using the current liquid formulation of Serenade ASO on canola because the product loses efficacy quickly under dry soil conditions after seeding (29). Product formulation and delivery strategies may be improved to enhance the survival of BCA after seeding. Our study also confirms the ability of this B. subtilis strain to colonize canola roots, which may be a critical element for the antibiosis, competition, and induced resistance in biocontrol. The study of transcript levels of nine defense-related genes revealed that ISR is stimulated with a soil-drench treatment of Serenade, and this is the first report on ISR in a crucifer species mediated by a Bacillus sp. BCA.

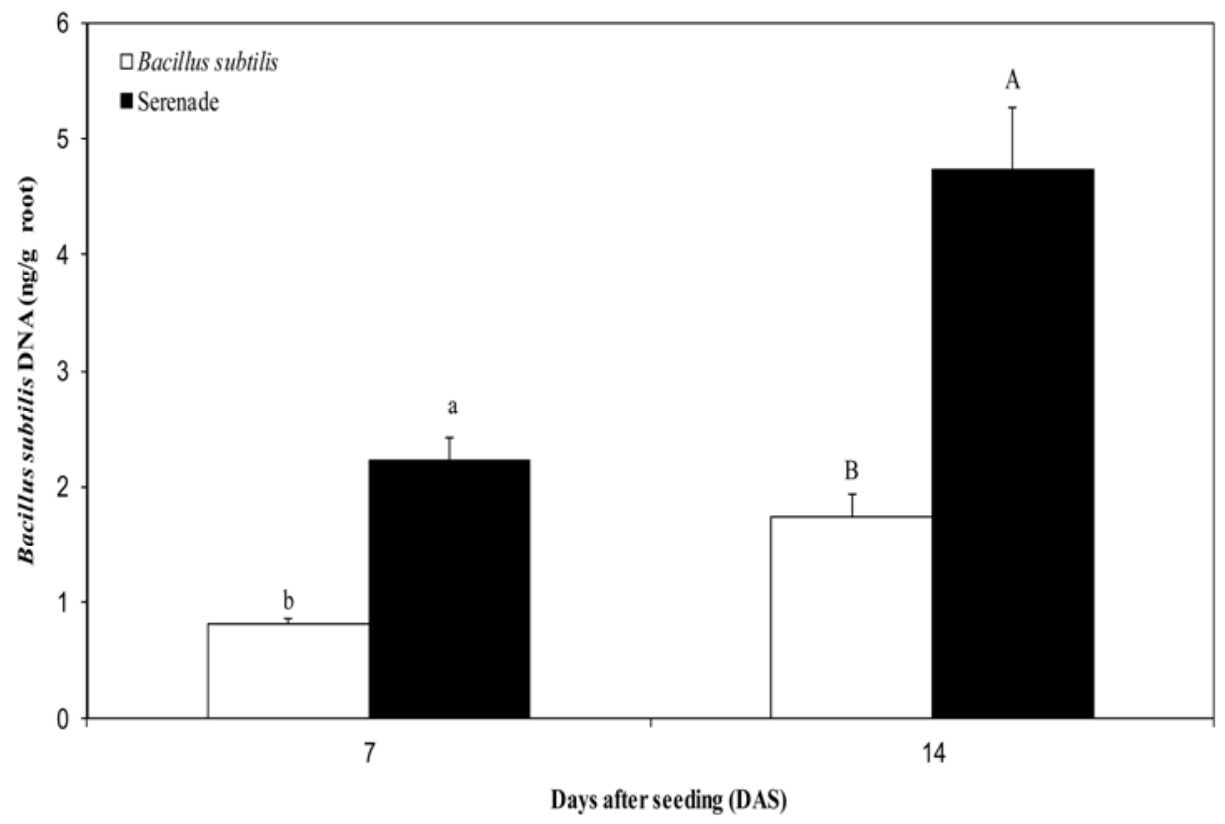

Fig. 3. Quantitative polymerase chain reaction quantification of Bacillus subtilis in canola roots after a soil drench treatment with a B. subtilis culture suspension or Serenade at 7 and 14 days after seeding (DAS). Roots of each plant were washed and rinsed to remove most of the microbes on root surfaces prior to testing. Bars represent the average of six replicates of each treatment. Mean amounts of B. subtilis DNA detected in canola roots at 7 DAS (lowercase letters) or 14 DAS (uppercase letters) marked with different letters are significantly different (least significant difference, $P<0.05$ ). Capped lines represent standard errors.

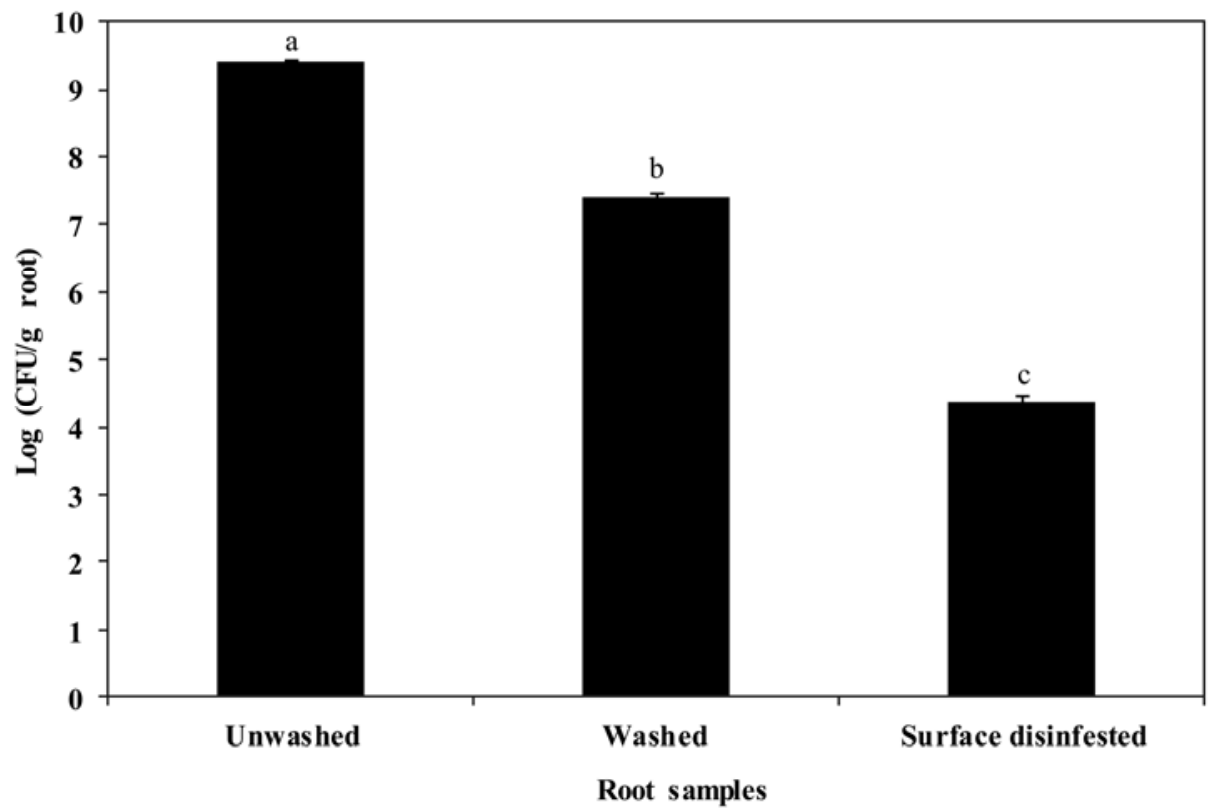

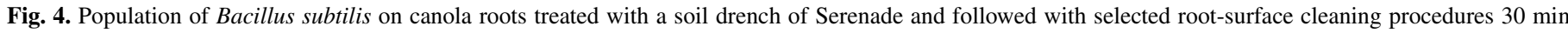

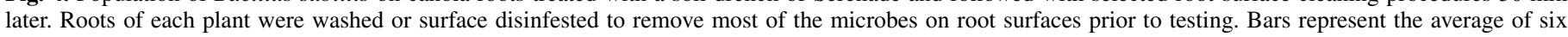

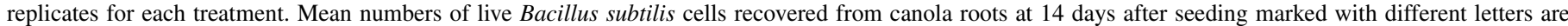

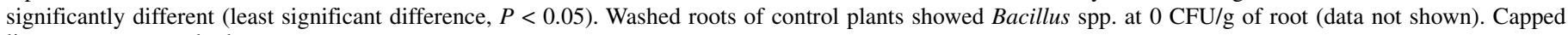
lines represent standard errors, 
In a previous study, the biofungicide Serenade suppressed clubroot on canola under controlled conditions but showed inconsistent performance in field trials when applied as a liquid in furrow at 13 liters/ha in a 500-liter carrier volume (41). This method of application is impractical in extensive-scale canola production due to the requirement of high water volumes. Granular and seed-dressing formulations of B. subtilis did not enhance the efficacy substantially in subsequent field trials (40). A better understanding of the biocontrol mechanism may help guide future efforts in formulation development. Antimicrobial secondary metabolites are often associated with BCAs in the genus Bacillus, including lipopeptides (39,42), cell-wall-degrading enzymes (chitinase and $\beta$-1,3-glucanase) and even antifungal volatiles $(3,33)$. These metabolites may act directly on the pathogen and, at the same time, facilitate rapid establishment of BCAs in the rhizosphere by minimizing the competition from other soil micro-

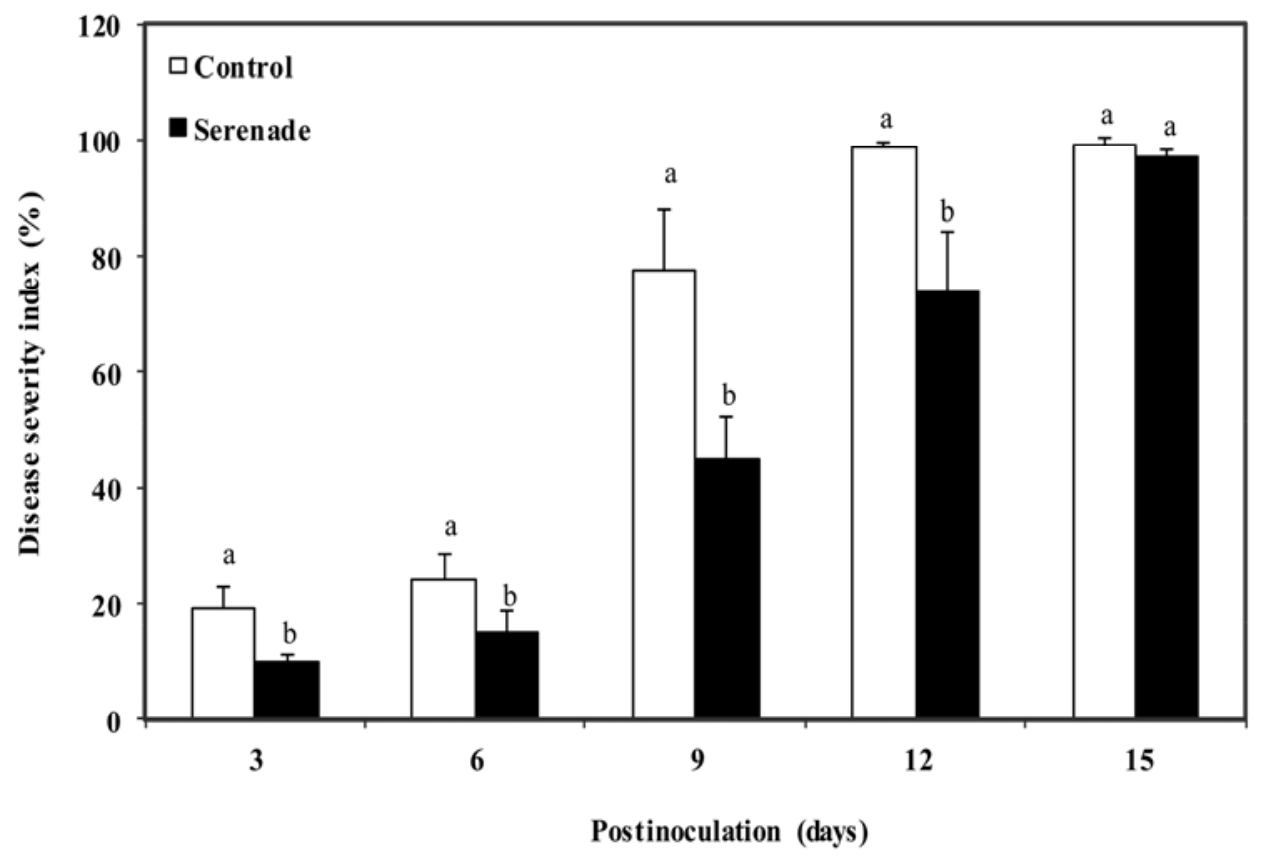

Fig. 5. Infection severity by Leptosphaeria maculans on cotyledons of canola 'Westar' treated with a soil drench of Serenade or water (control) at seeding. Bars represent the average of 72 replicates for each treatment. Mean disease severity indices between control and treated plants on a given date marked with different letters are significantly different (least significant difference, $P<0.05$ ). Capped lines represent standard errors,

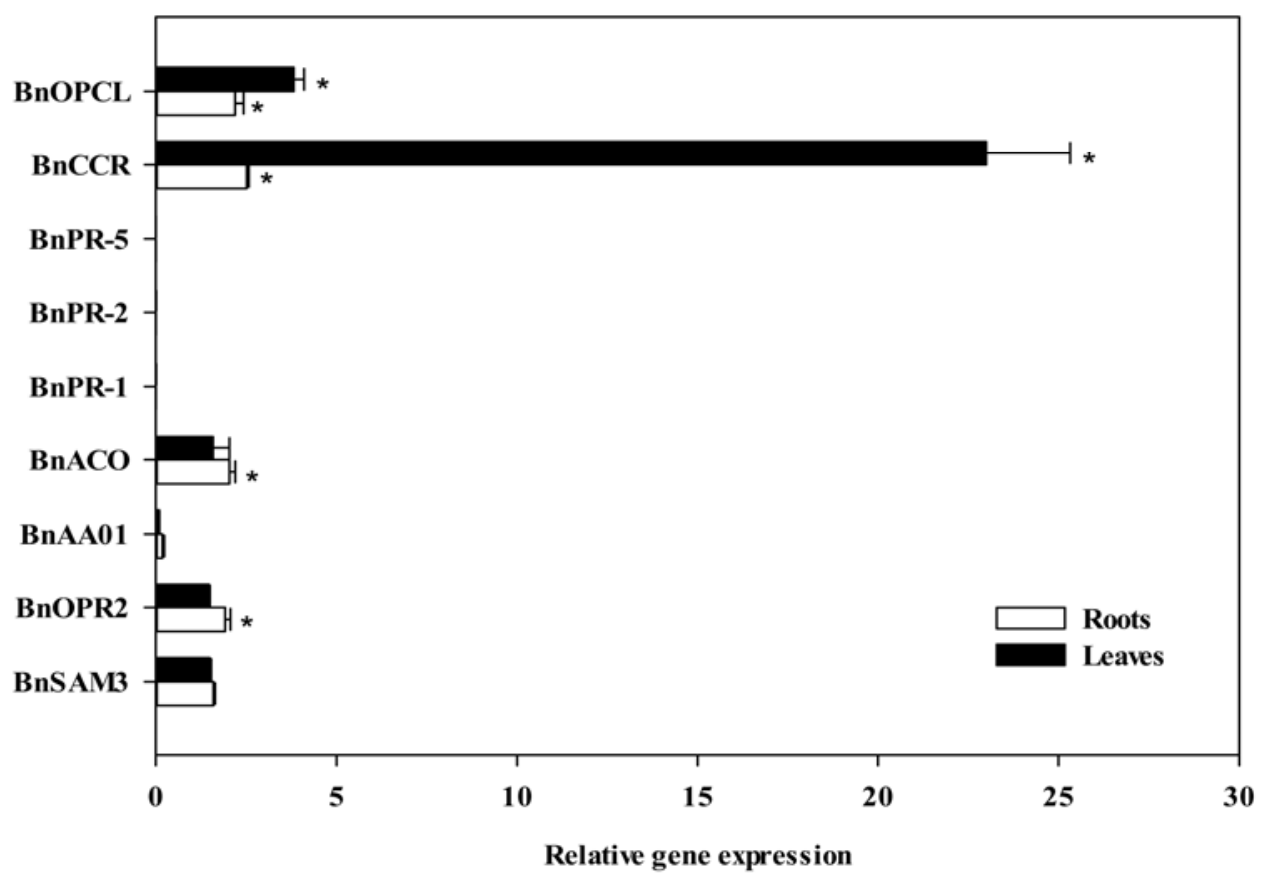

Fig. 6. Analysis of quantitative reverse-transcriptase polymerase chain reaction (PCR) using quantitative PCR over nine plant-defense-related genes (on vertical axis) in canola seedlings treated with a soil drench of Serenade or water (control). The expression of three pathogenesis-related (PR) genes (PR-1, PR-2, and PR-5) and genes that regulate ethylene (BnSAM3 and BnACO), auxin (BnAA01), jasmonic acid (OPR2), or phenylpropanoid (4-cournarate CoA ligase [OPCL] and c-innamoyl CoA reductase [BnCCR]) pathways were measured using root and first true leaf samples taken at 14 days after seeding. Gene expression levels were calibrated with that of the actin gene (62), and data from two separate tests were pooled for analysis. Capped lines represent standard errors. A gene was considered upregulated when its expression level was substantially higher $\left(^{*}\right)$ in treated plants relative to that of the control (least significant difference, $P<0.05$ ). 
organisms (26). The lipopeptide surfactins produced by this strain of B. subtilis (25) may also increase the surface motility of BCAs $(34,47)$, which might enable the BCA to interfere with $P$. brassicae zoospores more effectively (19). In a previous study, Serenade showed little or no effect on germination or viability of $P$. brassicae resting spores (29). The current study targeted zoospores, which are the weakest links in the pathogen's life cycle (11), using selected biofungicide components and application timings to assess the relative importance of various product ingredients against the primary and secondary phases of infection. This information can be useful for the improvement of product formulation and application that optimize the longevity and performance of the biofungicide in soil.

When the product filtrate or B. subtilis cells were applied only once, after seeding or transplanting, into the growth medium inoculated with $P$. brassicae (Table 1, target A or B), these treatments were slightly effective or ineffective in controlling clubroot. Efficacy was improved when these biofungicide components were applied at both seeding and transplanting (Table 1, target $\mathrm{C}$ ). This application timing targets infection of root hairs and root or cortical tissues, respectively, by primary and secondary zoospores. These zoospores would typically peak between 7 and 21 DAS (48) and these two-application treatments likely helped maintain high doses of biofungicide components for this duration (35). Throughout the study, Serenade was consistently more effective than either of its components applied alone. The initial root colonization by a BCA is often slow (17) but Serenade appears to have colonized canola roots extensively at 7 DAS. Inclusion of both B. subtilis and secondary metabolites in the product formulation may facilitate rapid colonization of the rhizosphere by inhibiting other soil microbes (26). Once established in the rhizosphere, this $B$. subtilis strain produces iturins and surfactins (25) that would further protect roots from soilborne pathogens. The notion that secondary metabolites help root colonization by the BCA is also supported by the results of qPCR data. These showed that populations of B. subtilis in canola roots treated with Serenade, as estimated by the amount of its DNA present on roots, were consistently higher than in those treated with a bacterial suspension alone (Fig. 3). It needs to be pointed out that the quantification of $B$. subtilis using $\mathrm{qPCR}$ was to estimate the relative population size of the bacterium among treatments, and the absolute number of bacterial cells in canola roots was not determined. Although the B. subtilis DNA was extracted from plant tissues that may have contained inhibitors which may cause biased DNA quantification, this does not detract from differences observed between the treatments because the same amount of plant material was included in each treatment. The same argument also applies to the qPCR of $P$. brassicae DNA in canola roots, where a standard curve was developed using pure $P$. brassicae resting spores.

Serenade and its components reduced RHI at 7 and 14 DAS, and these results correlated strongly ( $r=0.95$ and 0.84 , respectively) with the amount of $P$. brassicae DNA detected in roots at the same time. During this period, RHI might have peaked but root or cortical infection was likely still at an early stage $(35,48)$. In each case, the components applied alone were only partially effective. Even Serenade did not eliminate RHI completely. This may be one of the reasons for slightly weaker correlations $(r=$ 0.76 to 0.60 ) between the qPCR data and DSI. In fact, small amounts of $P$. brassicae DNA were often found in Serenadetreated canola roots early on but severe clubroot symptoms rarely developed eventually. There appeared to be additional mechanisms that inhibit the pathogen or disease development in these treated plants.

Induced resistance was indicated in canola plants treated with Serenade. Induced resistance may be divided into two broad categories: systemic acquired resistance (SAR) and ISR (28). SAR is often induced by a pathogen infection and PR proteins generally are involved via the SA-dependent pathways. ISR is usually a host response caused by rhizobacteria through upregulation of the JA- and Et-dependent pathways $(45,46,56)$. ISR has been reported with some Bacillus spp. $(31,38)$, and may interfere with the development of $P$. brassicae plasmodia after the initial infection of cortical tissues. We assessed the relative expression (transcript levels) of nine host-defense-related genes in canola roots and leaves following a soil-drench treatment with Serenade in the absence of $P$. brassicae. In the roots, the genes that were strongly upregulated included those encoding for JA (BnOPR2), Et (BnACO), and phenylpropanoids (BnCCR and BnOPCL). In contrast, only the genes relating to phenylpropanoids were activated in leaves. Genes encoding auxin (BnAA01) and PR proteins 1, 2, or 5 were not affected in roots or leaves. These results indicate that the biofungicide Serenade is able to induce resistance in canola roots.

Further, the induction of resistance was translocated to leaves where ISR inhibited infection by the foliar pathogen L. maculans. Increased gene activities (L-PAL) for phenylpropanoids can lead to enhanced amounts of phenolic compounds, which aid in general resistance, including increased lignification in the cell wall, or specific resistance responses such as the production of phytoalexins (30). The resistance response caused by Serenade appears to be a typical ISR (44) via elevated JA/Et and phenylpropanoid pathways, whereas PR proteins seem not to be involved. Because this is an initial investigation of ISR for Serenade, only the whole product was used. There is a slight possibility that the ISR observed was caused by the physiological stress factors from the product filtrate. The $\mathrm{pH}$ of the $5 \%$ Serenade suspension was 5.7 and that of the growth medium was 5.8 to 6.3 . Therefore, it is unlikely that the ISR caused by Serenade was due to acid stress.

The timing of ISR varies with inducer-host system, and is critical to the outcome of infection (55). In this study, upregulation of several defense-related genes at 14 DAS coincided with the peak release of $P$. brassicae secondary zoospores, and this timing may provide optimum protection against root infection and colonization by $P$. brassicae. Although Serenade and its components reduced RHI at 7 and 14 DAS, there was no indication that they induced the resistance of root hairs to infection. RHI by P. brassicae appears to be nonspecific (32) and occurs even in several nonhosts (15). RHI generally peaks between 6 and 8 DAS (22) in both resistant and susceptible canola cultivars. However, root colonization by secondary plasmodia develops quickly in susceptible cultivars but is suppressed in resistant cultivars (9). It is possible that root hairs are protected by antimicrobial metabolites and competition. Reduced RHI may lower the number of secondary zoospores produced and the pathogen inoculum available for root infection.

B. subtilis may be able to colonize plant roots endophytically via root hairs (21), and endophytic colonization by several Bacillus rhizobacteria plays a role in induced resistance functions (27). We hypothesized that $B$. subtilis in Serenade might also be able to penetrate canola roots. Although the rigorous washing procedure removed the majority of $B$. subtilis cells from canola root surfaces, a substantial bacterial population remained. Even the disinfestation used in this study did not eliminate BCA completely. Also, qPCR data highlighted a substantial $B$. subtilis population on canola roots even after repeated washing, and a substantial increase in the bacterial population between 7 and 14 DAS (Fig. 3). Therefore, we believe that the Bacillus spp. populations indicated by qPCR on washed roots (Fig. 3) are not sufficient to prove that the colonization of canola roots by $B$. subtilis is endophytic. Many Bacillus spp. are rhizosphere competent (26) and produce biofilms in the rhizosphere (47). This may explain why the washing procedure did not totally remove the bacterial population from the root surface. Serenade consistently resulted in a higher bacterial population than did the $B$. subtilis alone, and this may indicate that the bacteria in the Serenade product are more able to colonize 
canola roots than those in a pure bacterial suspension. Also, Serenade applied as a soil drench at seeding may result in a substantial B. subtilis population on canola roots for protection against root hair and cortical infections. Some Bacillus spp. produced ISR without the evidence of endophytic colonization $(38,47)$; therefore, endophytic root colonization by a BCA is not necessarily a prerequisite for ISR.

In conclusion, the biofungicide Serenade appears to suppress clubroot on canola via antibiosis and induced resistance, while other mechanisms may also play a role. Secondary metabolites contained in the product not only suppress infection by zoospores directly but also may facilitate the BCA to colonize the rhizosphere rapidly by suppressing other microbial competitors. The results on application timing demonstrate the need to maintain a high dose of the biofungicide in the soil to protect against both root hair and cortical infection. This need will likely require substantial improvements in product formulation, because this BCA has limited longevity in the soil when applied in a liquid form. Application of Serenade stimulated ISR in canola plants via upregulation of JA or Et and phenylpropanoid pathways. This mechanism should be explored further with the formulation development to maximize the efficacy of clubroot control.

\section{ACKNOWLEDGMENTS}

We thank the Canola Council of Canada, SaskCanola, and AAFC Pest Management Centre for financial support for this study; T. Tran and D. Head for technical assistance in carrying out DNA extraction and qPCR; J. Fransisco for providing assistance in running efficacy trials; and M. Hijri (University of Montreal) for reviewing the procedures for studying expression of host defense-related genes.

\section{LITERATURE CITED}

1. Agostini, J. P., Bushong, P. M., and Timmer, L. W. 2003. Greenhouse evaluation of products that induce host resistance for control of scab, melanose, and Alternaria brown spot of citrus. Plant Dis. 87:69-74.

2. Arie, T., Kobayashi, Y., Okada, G., Kono, Y., and Yamaguchi, I. 1998. Control of soilborne clubroot disease of cruciferous plants by epoxydon from Phoma glomerata. Plant Pathol. 47:743-748.

3. Arrebola, E., Sivakumar, D., and Korsten, K. 2009. Effect of volatile compounds by Bacillus strains on post-harvest decay in citrus. Biol. Control 53:122-128.

4. Bacon, C. W., and Hinton, D. M. 2002. Endophytic and biological control potential of Bacillus mojavensis and related species. Biol. Control 23:274-284.

5. Buczacki, S. T. 1983. Plasmodiophora. An inter-relationship between biological and practical problems. Pages 161-191 in: Zoosporic Plant Pathogens. S. T. Buczacki, ed. Academic Press, London.

6. Channon, A. G., and Maude, R. B. 1971. Vegetable diseases. Pages 323363 in: Diseases of Crop Plants. J. H. Western, ed. Macmillan and Co., New York.

7. Cheah, L. H., Veerakone, S., and Kent, G. 2000. Biological control of clubroot on cauliflower with Trichoderma and Streptomyces spp. N. Z. Plant Prot. 53:18-21.

8. Chen, C., Belanger, R. R., Benhamou, N., and Paulitz, T. C. 2000. Defense enzymes induced in cucumber roots by treatment with plant growth promoting rhizobacteria. Physiol. Mol. Plant Pathol. 56:13-23.

9. Deora, A., Gossen, B. D., and McDonald, M. R. 2012. Infection and development of Plasmodiophora brassicae in resistant and susceptible canola cultivars. Can. J. Plant Pathol. Online publication. doi:10.1080/ 07060661.2012.681071

10. Dixon, G. R. 2003. Clubroot, a case for integrated control. Plantsman 2:179-183.

11. Dixon, G. R. 2006. The biology of Plasmodiophora brassicae Wor.-a review of recent advances in the United Kingdom. Acta Hortic. 706:271282.

12. Dixon, G. R. 2009. The occurrence and economic impact of Plasmodiophora brassicae and clubroot disease. J. Plant. Growth Regul. 28:194202.

13. Donald, C., and Porter, I. 2009. Integrated control of clubroot. J. Plant. Growth Regul. 28:1-17.

14. Emmert, E. A. B., and Handelsman, J. 1999. Biocontrol of plant disease: A $\left(\mathrm{gram}^{+}\right)$positive perspective. FEMS Microbiol. Lett. 171:1-9.
15. Feng, J., Xiao, Q., Hwang, S. F., Strelkov, S. E., and Gossen, B. D. 2011. Infection of canola by secondary zoospores of Plasmodiophora brassicae produced on a nonhost (ryegrass). Eur. J. Plant Pathol. 132:309-315.

16. Fernando, W. G. D., Nakkeeran, S., Zhang, Y., and Savchuk, S. 2007. Biological control of Sclerotinia sclerotiorum (Lib.) de Bary by Pseudomonas and Bacillus species on canola petals. Crop Prot. 26:100-107.

17. Haas, D., and Defago, G. 2005. Biological control of soil-borne pathogens by Pseudomonas fluorescens. Nat. Rev. Microbiol. 3:307-319.

18. Harish, S., Kavino, M., Kumar, N., Saravanakumar, D., Soorianathasundaram, K., and Samiyappan, R. 2008. Biohardening with plant growth promoting rhizosphere and endophytic bacteria induces systemic resistance against banana bunchy top virus. Appl. Soil Ecol. 39:187-200.

19. Hildebrand, P. D., and McRae, K. B. 1998. Control of clubroot caused by Plasmodiophora brassicae with nonionic surfactants. Can. J. Plant Pathol. 20:1-11.

20. Howard. R. J., Strelkov, S. E., and Harding, M. E. 2010. Clubroot of Cruciferous crops-new perspectives on an old disease. Can. J. Plant. Pathol. 32:43-57.

21. Huang, B., Lu, C., Zhuang, P., Zhang, H., and Fan, L. 2011. Endophytic colonisation of Bacillus subtilis in the roots of Robinia pseudoacacia L. Plant Biol. 13:925-931.

22. Hwang, S. F., Ahmed, H. U., Strelkov, S. E., Gosen, B. D., Turnbull, G. D., Peng, G., and Howard, R. J. 2011. Seeding age and inoculum density affect clubroot severity and seed yield in canola. Can. J. Plant Sci. 91:183-190.

23. Jaschke, D., Dugassa-Gobena, D., Karlovsky, P., Vidal, S., and LudwigMuller, J. 2010. Suppression of clubroot (Plasmodiophora brassicae) development in Arabidopsis thaliana by the endophytic fungus Acremonium alternatum. Plant Pathol. 59:100-111.

24. Jorgensen, C., and Leser, T. D. 2007. Estimating amplification efficiency improves multiplex real-time PCR quantification of Bacillus licheniformis and Bacillus subtilis spores in animal feed. J. Microbiol. Methods 68:588595 .

25. Kinsella, K., Schulthess, C. P., Morris, T. M., and Stuart, J. D. 2009. Rapid quantification of Bacillus antibiotics in the rhizosphere. Soil Biol. Biochem. 41:374-379.

26. Kinsinger, R. F., Shirk, M. C., and Fall, R. 2003. Rapid surface motility and biofilm formation in Bacillus subtilis is dependent on extracellular surfactin and potassium ion. J. Bacteriol. 185:5627-5631.

27. Kloepper, J. W., Ryu, C. M., and Zhang, S. A. 2004. Induced systemic resistance and promotion of plant growth by Bacillus spp. Phytopathology 94:1259-1266

28. Korolev, N., Rav David, D., and Elad, Y. 2007. The role of phytohormones in basal resistance and Trichoderma-induced systemic resistance to Botrytis cinerea in Arabidopsis thaliana. BioControl 53:667-683.

29. Lahlali, R., Peng, G., McGregor, L., Gossen, B. D., Hwang, S. F., and McDonald, M. R. 2011. Mechanisms of the biofungicide Serenade (Bacillus subtilis QST713) in suppressing clubroot. Biocontrol Sci. Technol. 21:1351-1362.

30. Lattanzio, V., Latanzio, V. M. T., and Cardinali, A. 2006. Role of phenolics in the resistance mechanisms of plants against fungal pathogens and insects. In: Phytochemistry: Advances in Research. F. Imperato, ed. Research Signpost 37/661 (2), Fort P.O., Trivandrum-695 023, Kerala, India.

31. Lian, L., Xie, L., Zheng, L., and Lin, Q. 2011. Induction of systemic resistance in tobacco against Tobacco mosaic virus by Bacillus spp. Biocontrol Sci. Technol. 21:281-292.

32. Ludwig-Müller, J., Bennett, R. N., Kiddle, G., Ihmig, S., Ruppel, M., and Hilgenberg, W. 1999. The host range of Plasmodiophora brassicae and its relationship to endogenous glucosinolate content. New Phytol. 144:443458.

33. Manjula, K., and Podile, A. R. 2005. Production of fungal cell wall degrading enzymes by a biocontrol strain of Bacillus subtilis AF 1. Indian J. Exp. Biol. 43:892-896.

34. Nagorska, K., Bikowski, M., and Obuchowski, M. 2007. Multicellular behaviour and production of a wide variety of toxic substances support usage of Bacillus subtilis as a powerful biocontrol agent. Acta Biochim. Pol. 54:495-508.

35. Naiki, T., and Dixon, G. R., 1987. The effects of chemicals on development stages of Plasmodiophora brassicae (clubroot). Plant Pathol. 36: 316-327.

36. Narisawa, K., Tokumasu, S., and Hashiba, T. 1998. Suppression of clubroot formation in Chinese cabbage by the root endophytic fungus, Heteroconium chaetospira. Plant Pathol. 47:206-210.

37. Newman, P. L. 1980. Genetic aspects of blackleg (Leptosphaeria maculans) resistance in rapeseed (Brassica napus). Ph.D. thesis, University of Wisconsin, Madison.

38. Ongena, M., Duby, F., Jourdan, E., Beaudry, T., Jadin, V., Dommes, J., and Thonart, P. 2005. Bacillus subtilis M4 decreases plant susceptibility towards fungal pathogens by increasing host resistance associated with 
differential gene expression. Appl. Microbiol. Biotechnol. 67:692-698.

39. Ongena, M., and Jacques, P. 2008. Bacillus lipopeptides: versatile weapons for plant disease biocontrol. Trends Microbiol. 16:115-125.

40. Peng, G., Lahlali, R., Pageau, D., Hwang, S. F., Hynes, R. K., Anderson, K., McDonald, M. R., Gossen. B. D., Strelkov, S. E., Turkington, T. K., Yu, F. Q., Falk, K. C., Boyetchko, S. M., McGregor, L., Hupka, D., and Geissler, J. Assessment of crop rotation and host resistance in combination with Bacillus subtilis biofungicides for clubroot management on canola (Abstract). Can. J. Plant Pathol. (In press.)

41. Peng, G., McGregor, L., Lahlali, R., Gossen, B. D., Hwang, S. F., Adhikari, K. K., Strelkov, S. E., and McDonald, M. R. 2011. Potential biological control of clubroot on canola and crucifer vegetable crops. Plant Pathol. 60:566-574

42. Peypoux, F., Bonmatin, J. M., and Wallach, J. 1999. Recent trend in the biochemistry of surfactin. Appl. Microbiol. Biotechnol. 51:553-563.

43. Philip, L., Lyengar, L., and Venkobachar, C. 1998. Cr (VI) reduction by Bacillus coagulans isolated from contaminated soils. J. Environ. Eng. 124:1165-1170.

44. Pieterse, C. M. J., and van Loon, L. C. 2004. NPR1: The spider in the web of induced resistance signaling pathways. Curr. Opin. Plant Biol. 7:456464.

45. Pieterse, C. M. J., Van Wees, S. C. M., Van Pelt, J. A., Knoester, M., Laan, R., Gerrits, H., Weisbeek, P. J., and Van Loon, L. C. 1998. A novel signaling pathway controlling induced systemic resistance in Arabidopsis. Plant Cell 10:1571-1580.

46. Potlakayala, S., Reed, D. W., Covello, P. S., and Fobert, P. R. 2007. Systemic acquired resistance in canola is linked with pathogenesis related gene expression and requires salicylic acid. Phytopathology 97:794-802.

47. Rudrappa, T., Biedrzycki, M. L., and Bais, H. P. 2008. Causes and consequences of plant-associated biofilms. FEMS Microbiol. Ecol. 64:153-166.

48. Sharma, K., Gossen, B. D., and McDonald, M. R. 2011. Effect of temperature on cortical infection by Plasmodiophora brassicae and clubroot severity. Phytopathology 101:1424-1432.

49. Strelkov, S. E., Hwang, S. E., Howard, R. J., Hartman, M., and Turkington, T. K. 2011. Progress towards the sustainable management of clubroot (Plasmodiophora brassicae) of canola on the Canadian prairies. Prairie Soils Crops 4:114-121.

50. Strelkov, S. E., Tewari, J. P., and Smith-Degenhardt, E. 2006. Characterization of Plasmodiophora brassicae populations from Alberta, Canada. Can. J. Plant Pathol. 28:467-474.

51. Sundelin, T., Christensen, C. B., Larsen, J., Moller, K., Lubeck, M.,
Bodker, L., and Jensen, B. 2010. In planta quantification of Plasmodiophora brassicae using signature fatty acids and real-time PCR. Plant Dis. 94:432-438

52. Surette, M., Sturz, A., Lada, R., and Nowak, J. 2003. Bacterial endophytes in processing-carrots (Daucus carota L. car. Sativus): Their localisation, population density, biodiversity and their effects on plant growth. Plant Soil 253:381-390.

53. Tanaka, S., Kochi, S., Kunita, H., Ito, S. I., and Kameya-Iwaki, M. 1999. Biological mode of action of the fungicide, flusulfamide, against Plasmodiophora brassicae (clubroot). Eur. J. Plant. Pathol. 105:577-584.

54. Tewari, J. P., Strelkov, S. E., Orchard, D., Hartman, M., Lange, R., and Turkington, T. K. 2005. Identification of clubroot of crucifers on canola (Brassica napus) in Alberta. Can. J. Plant Pathol. 27:143-144.

55. Vallard, G. E., and Goodman, R. M. 2004. Systemic acquired resistance and induced systemic resistance in conventional agriculture. Crop Sci. 44:1920-1934

56. Van Loon, L. C., Baker, P. A. H. M., and Pieterse, M. J. 1998. Systemic resistance induced by rhizosphere bacteria. Annu. Rev. Phytopathol. 36:453-483.

57. Viswanathan, R., and Samiyappan, R. 1999. Induction of systemic resistance by plant growth promoting rhizobacteria against red rot disease in sugarcane. Sugarcane Technol. 1:67-76.

58. Viswanathan, R., and Samiyappan, R. 2001. Antifungal activity of chitinases produced by some fluorescent Pseudomonads against Colletotrichum falcatum Went. causing red rot disease in sugarcane. Microbiol. Res. 155:309-314.

59. Weller, D. M., Mavrodi, D. V., van Pelt, J. A., Pieterse, C. M. J., van Loon, L. C., and Bakker, P. A. H. M. 2012. Induced systemic resistance in Arabidopsis thaliana against Pseudomonas syringae pv. tomato by 2,4diacetylphloroglucinol-producing Pseudomonas fluorescens. Phytopathology 102:403-412.

60. West, J. S. Kharbanda, P. D., Barbetti, M. J., and Fitt, B. D. L. 2001 Epidemiology and management of Leptosphaeria maculans (Phoma stem canker) on oilseed rape in Australia, Canada and Europe. Plant Pathol. 50:10-27.

61. Zdor, R. E., and Anderson, A. J. 1992. Influence of root colonizing bacteria on the defense responses in bean. Plant Soil 140:99-107.

62. Zhao, J., Buchwaldt, L., Rimmer, S. R., Sharpe, A., McGregor, L., Bekkaoui, D., and Hegedus, D. 2009. Patterns of differential gene expression in Brassica napus cultivars infected with Sclerotinia sclerotiorum. Mol. Plant Pathol. 10:635-649. 